\title{
Development and in vitro evaluation of sustained release multiparticulate tablet of freely water soluble drug
}

\author{
Ashlesha Pravin Pandit ${ }^{1 *}$, Rajendra Dattatray Shinde ${ }^{2}$ \\ ${ }^{1}$ Department of Pharmaceutics, Sinhgad College of Pharmacy, Pune, India, ${ }^{2}$ Department of Pharmaceutics, \\ SKN College of Pharmacy, Pune, India
}

\begin{abstract}
Blends of aqueous dispersion of a hydrophobic and hydrophilic polymer, namely Surelease ${ }^{\circledR}$ : hydroxypropyl methylcellulose (Surelease ${ }^{\circledR}$ : HPMC E15) were used as coating materials to control the drug release from coated pellets of the highly water soluble drug metoprolol succinate. Varying the polymer blends, ranges of drug release patterns were obtained at $\mathrm{pH}$ 6.8. The present study dealt with diffusion of drug through plasticized Surelease ${ }^{\circledR /}$ hydroxypropyl methylcellulose (HPMC E15) films prepared by coating of drug and polymers onto non-pareil seeds using the solution layering technique. The release of metoprolol succinate from coated pellets was decreased with increased coating load of polymer. The optimized formulation was obtained by $3^{2}$ full factorial design. The release profile revealed that the optimized formulation follows zero order release kinetics. The stability data showed no interaction for storage at $25^{\circ} \mathrm{C}$ and $60 \%$ relative humidity.
\end{abstract}

Uniterms: Pellets. Nonpareil seeds. Surelease ${ }^{\circledR}$. HPMC E15. Coating. Solution layering technique. Cushning agent. Metoprolol succinate.

\begin{abstract}
Misturas das dispersões aquosas de polímero hidrofóbico e de polímero hidrofílico, a saber, Surelease ${ }^{\circledR}$ : hidroxipropil metilcelulose (Surelease ${ }^{\circledast}$ : HPMC E15), foram utilizadas como material de revestimento para controlar a liberação de fármacos de péletes revestidos de fármaco altamente solúvel, o succinato de metoprolol. Variando as misturas de polímeros, obtiveram-se faixas de padrão de liberação do fármaco $\mathrm{em} \mathrm{pH} 6,8$. O presente estudo tratou da difusão do fármaco através de filmes de Surelease ${ }^{\circledR} /$ hidroxipropil metilcelulose(HPMC E15), preparados pelo revestimento do fármaco e dos polímeros em sementes nonpareil, utilizando técnica de solução em camada. A liberação de succinato de metoprolol dos péletes revestidos diminuiu com o aumento da carga de polímero de revestimento. A formulação otimizada foi obtida por planejamento fatorial $3^{2}$. O perfil de liberação revelou que a formulação otimizada segue a cinética de liberação de ordem zero. Os dados de estabilidade mostraram não haver interação por armazenamento a $25^{\circ} \mathrm{C}$ e umidade relativa de $60 \%$.
\end{abstract}

Unitermos: Péletes. Nonpareil. Surelease ${ }^{\circledR}$. HPMC E15. Revestimento. Técnica da solução em camada. Agente de cushning. Succinato de metoprolol.

\section{INTRODUCTION}

Developing oral sustained release systems for freely water soluble drugs having strong first pass metabolism has always posed a challenge to the pharmaceutical technologist. Most of these highly water soluble drugs, if not formulated properly, are released at a high rate and are

\footnotetext{
*Correspondence: A. P. Pandit. Department of Pharmaceutics, Sinhgad College of Pharmacy, S.No. 44/1, Vadgaon (Bk.), Off Sinhgad Road, Pune-411 041, Maharashtra, India. E-mail: panditashleshap@rediffmail.com
}

likely to produce toxic concentrations when administered orally (Lian-Dong, Yang, Xing, Qian, 2006). Polymeric film coatings are often used for achieving sustained release of an active substance from pharmaceutical formulation because a coated dosage form enables prolonged and precise release of drug with good reproducibility (Sousa, Sousa, Moura, Newton, 2002; Vaithiyalingam, Khan, 2002). One of the most widely used hydrophobic polymers in pharmaceutical film coating is ethyl cellulose $\left(\right.$ Surelease $\left.{ }^{\circledR}\right)$, due to its convenient film formability, good physiochemical properties and minimum toxicity 
(Mcginity, 1997). Surelease ${ }^{\circledR}$ is a good polymer for modified release coating. The polymer is usually used in combination with a secondary polymer such as hydroxypropyl methylcellulose (HPMC E15) which confers the film a more hydrophilic nature and alters its structure by virtue of pores and channels through which the drug substance can diffuse more easily to control the release properties of a drug formulation (Aulton, Bdul-Razzak, Hogan, 1981). Surelease ${ }^{\circledR}$ containing plasticizer is essential to enhance film forming characteristics, workability and serviceability (Frenning, Tuno'N, Alderborn, 2003). Pellets as a drug delivery system offer not only technological advantages but also better flow properties, less friable dosage form, narrow particle size distribution, ease of coating, and uniform packing (Siepmann, Siepmann, Walther, Macrae, Bodmeier, 2005). It also has therapeutic advantages such as less irritation of the gastrointestinal tract, a low risk of side effects associated with dose dumping and reduction of the variation in gastric emptying rates (Evdokia, 2000). Coating of pellets in a coating pan with a polymer is often used as a means of controlling the drug release rate from extended release formulations. The coated pellets can be compacted into multiple unit tablets or used to fill hard gelatin capsules. Both formulations are normally intended to release intact reservoir pellets after administration; thus the overall drug release rate is determined by the release rate from single pellet units.

Metoprolol succinate, a white crystalline powder, is freely soluble in water. Since the solubility of metoprolol succinate is lower at neutral $\mathrm{pH}$, compared to acidic $\mathrm{pH}$, it is released by the mechanism of diffusion through an insoluble polymer film (Ye, Rombout, 2007). It is a cardio selective $\beta$-blocker that has been classified as a class I substance according to the Biopharmaceutics Classification System, meaning that it is highly soluble and highly permeable. The drug is readily and completely absorbed throughout the intestinal tract (Rahman, Yuen, 2006) but is subjected to extensive first pass metabolism resulting in incomplete bioavailability (about 50\%). After a single oral dose, peak plasma concentration occurs after about 1 to $2 \mathrm{~h}$. The drug is eliminated within 3 to $4 \mathrm{~h}$ which, depending on therapeutic activity, makes it necessary to administer the formulation up to 4 times daily. Based on these properties and well defined relationship between the beta blocking effect and plasma drug concentration, metoprolol lends itself to a sustained release formulation.

The goal of this study was to develop a sustained release multiparticulate dosage form as a tablet of metoprolol succinate to reduce the dosing frequency from three times to once a day, and to study the stability of these formulations. Sustained release multiparticulate tablets of metoprolol succinate were prepared by the compression technique in which sustained release pellets were mixed with the cushning agent micro-crystalline cellulose (Avicel $^{\circledR}$ PH 102), superdisintegrant Indion 414 and lubricant magnesium stearate.

\section{MATERIAL AND METHODS}

\section{Material}

The following chemicals were procured from commercial suppliers:

Surelease ${ }^{\circledR}$ NG, E-7-1905, (Colorcon Asia Pvt. Ltd., Goa); hydroxypropyl methylcellulose (HPMC) E15, potassium dihydrogen phosphate, hydrochloric acid 35.4\%, sodium hydroxide, magnesium stearate , talc (all Loba Chemie Pvt. Ltd., Mumbai), Indion 414 (Ion Exchange India Limited, Mumbai, India), microcrystalline cellulose (Avicel ${ }^{\circledR}$ PH102, Que Pharma Pvt. Ltd., Wadhwan), non-pariel seeds (Salus Pharmaceuticals, Ahmedabad), metoprolol succinate (Glenmark Pharma Pvt. Ltd., Goa). Distilled water was used throughout the work. All other reagents were of analytical grade.

\section{Methods}

Preparation of sustained release pellets of metoprolol succinate

\section{- Preparation of drug pellets}

Metoprolol succinate $20 \% \mathrm{w} / \mathrm{v}$ was mixed with a $1 \% \mathrm{w} / \mathrm{v}$ aqueous binder solution of polyvinyl pyrrolidone (PVP) K30 and 2\% w/v talc with continuous stirring (Rahman, Yuen, 2006). This drug solution was sprayed onto $200 \mathrm{~g}$ of uncoated pellets as non pariel seeds of 14/16 mesh of size $850-1100 \mu \mathrm{m}$ by the solution layering technique in a coating pan (Instacoat R \& D Coater, Ideal Cures Pvt. Ltd., Mumbai, India). The drug layering conditions were as shown in Table I.

\section{- Preparation of polymer dispersion}

An aqueous dispersion of Surelease ${ }^{\circledR}$ was diluted to $15 \% \mathrm{w} / \mathrm{v}$ with distilled water. Similarly, a $5 \%$ solution of HPMC E15 was prepared in water by dispersing the powder of HPMC E15 in $50 \mathrm{ml}$ of preheated water (80$90^{\circ} \mathrm{C}$ ) and then diluting it with an additional $50 \mathrm{ml}$ of cold water. The solution was kept overnight. Varying polymer blends of Surelease ${ }^{\circledR}$ and HPMC E15 were selected for the polymer dispersion of sustained release formulation. To reduce foam, the anti-foaming agent oleic acid was added to the dispersion. 
Coating of drug pellets with polymer dispersion

In a mixture of dispersion of varying concentrations of Surelease ${ }^{\circledR}$ and HPMC E15, a small quantity of talc (2\% $\mathrm{w} / \mathrm{v}$ ) was added as an anti-adherent to the coating mixture. The mixture was stirred using a magnetic stirrer prior to and throughout the coating process. The drug pellets (200 g) were coated at different coating loads by the solution layering technique. Coating parameters were set as shown in Table I. The coating fluid was sprayed onto the pellets with an intermittent drying time of $5 \mathrm{~min}$ in a coating pan.

TABLE I - Coating parameters required during coating

\begin{tabular}{lccc}
\hline Conditions & Preheating & Coating & Drying \\
\hline Inlet air temperature $\left({ }^{\circ} \mathrm{C}\right)$ & $55-60$ & $65-70$ & 50 \\
Product temperature $\left({ }^{\circ} \mathrm{C}\right)$ & $40-45$ & $50-55$ & $40-45$ \\
Outlet air temperature $\left({ }^{\circ} \mathrm{C}\right)$ & $35-40$ & $40-45$ & $40-45$ \\
Spray rate $(\mathrm{ml} / \mathrm{min})$ & - & $3-4$ & - \\
Atomizing air pressure $(\mathrm{psi})$ & - & 20 & - \\
Pan speed $(\mathrm{rpm})$ & $35-37$ & $35-37$ & $35-37$ \\
\hline
\end{tabular}

\section{Formulation optimization (factorial design)}

The optimization of batch was carried out by $3^{2}$ full factorial design as shown in Table II.

TABLE II - Factorial design data

\begin{tabular}{lcccc}
\hline Independent & Coded & \multicolumn{3}{c}{ Levels } \\
\cline { 3 - 5 } Variables $^{\text {units }}$ & -1 & 0 & 1 \\
\hline Surelease $^{\circledR}:$ HPMC & $\mathrm{X} 1$ & $70: 30$ & $80: 20$ & $90: 10: 00$ \\
E15 & & & & \\
Coating level (\%) & $\mathrm{X} 2$ & 15 & 20 & 25 \\
\hline
\end{tabular}

Levels $-1,0$ and +1 indicates lower, middle and higher level for factorial data

Different formulation codes were assigned to the batches of ratios of Surelease ${ }^{\circledR}$ : HPMC E15 and polymer coating loads. Formulation code F1 indicated the content of Surelease ${ }^{\circledR}$ and HPMC E15 in the ratio of $70: 30$ of $15 \%$ coating load. Formulation codes F2 to F9, assigned to the varying blends of polymer and coating load, are as shown in Table III. In the factorial design, dependent variables are $\mathrm{Y} 1$ as drug release (\%), Y2 as $\mathrm{t}_{50 \%}(\mathrm{~h}), \mathrm{Y} 3$ as $\mathrm{t}_{80 \%}(\mathrm{~h})$ and independent variables are $\mathrm{X} 1$ as ratio of Surelease ${ }^{\circledR}$ : HPMC E15, and X2 as coating load (\%).

\section{Curing time}

After coating, the pellets were further cured at $40^{\circ} \mathrm{C}$ at $75 \%$ relative humidity for $24 \mathrm{~h}$ (Lecomte, 2004)
TABLE III - Different combinations of polymers and coating thickness

\begin{tabular}{lcc}
\hline Formulation & \multicolumn{2}{c}{ Variable Factors } \\
\cline { 2 - 3 } & X1 & X2(\%) \\
\hline F1 & $70: 30$ & 15 \\
F2 & $70: 30$ & 20 \\
F3 & $70: 30$ & 25 \\
F4 & $80: 20$ & 15 \\
F5 & $80: 20$ & 20 \\
F6 & $80: 20$ & 25 \\
F7 & $90: 10$ & 15 \\
F8 & $90: 10$ & 20 \\
F9 & $90: 10$ & 25 \\
\hline X1- ratio of combinations of Surelease ${ }^{\circledR:}$ HPMC E15; X2-\% &
\end{tabular}

\section{Characterization of pellets}

Non pareil seeds were evaluated visually to check the spherical nature. The flow property of these was studied using the following tests:

- Carr's index

Carr's index value for uncoated pellets and coated pellets were determined using formula (Aulton M., 2002):

Carr's Index $(\%)=\frac{(\text { Tapped density }- \text { Fluff density })}{\text { Tapped density }} \times 100$

- Angle of repose

The static angle of repose of uncoated pellets and coated pellets was measured by the fixed funnel and free-standing cone method (Aulton M., 2002) using the formula:

$$
\text { Angle of repose }(\theta)=\tan ^{-1} \mathrm{~h} / \mathrm{r}
$$

where: h-height of the heap; r-radius of the flat surface occupied by pellets

- Drug content

Sustained release pellets (400 mg) of MS were triturated and dissolved in $100 \mathrm{ml}$ distilled water. Further dilutions were made using $\mathrm{pH} 6.8$ phosphate buffer solutions. The amount of drug content was estimated UV spectrophotometrically (JASCO V-530, Japan) at $274 \mathrm{~nm}$.

\section{In vitro dissolution}

Dissolution testing of formulations F1-F9 was performed using USP XXVIII type I. The test was performed 
using $500 \mathrm{ml}$ solution of $\mathrm{pH} 6.8$ phosphate buffer maintained at temperature $37 \pm 0.5^{\circ} \mathrm{C}$ stirred at a speed of 50 rpm (United State Pharmacopoeia, 2005). A sample of 5 $\mathrm{ml}$ was taken out at an interval of $0.5,1,1.5,2,3,4,6,8$, $10,12,13,14,20,21,22,23$ and $24 \mathrm{~h}$ and immediately replaced with $5 \mathrm{ml}$ fresh $\mathrm{pH} 6.8$ phosphate buffer solution to maintain sink conditions in the dissolution jar. The drug content was analyzed at $274 \mathrm{~nm}$ using a UV spectrophotometer (Jasco, Japan).

\section{Sustained release metoprolol succinate tablets}

Sustained release pellets having a cushning agent of micro-crystalline cellulose and superdisintegrant of Indion 414 were compressed in a six stations rotary tablet machine (General Machinery Co., Mumbai) equipped with flat-faced punch with a diameter of $9 \mathrm{~mm}$ and length of $16 \mathrm{~mm}$ after lubrication of the punch and die by dusting with magnesium stearate to achieve a $700 \mathrm{mg}$ multiparticulate sustained release tablet (Table IV).

TABLE IV - Composition of multiparticulate sustained release tablet

\begin{tabular}{lc}
\hline Ingredients & Quantity $(\mathrm{mg})$ \\
\hline coated sustained release pellets & 227.27 \\
Microcrystalline cellulose PH 102 & 272.73 \\
Starch & 191.75 \\
Indion 414 & 7.5 \\
Magnesium stearate & 0.75 \\
\hline Total & 700 \\
\hline
\end{tabular}

Cushning agents protected the polymer coat while superdisintegrant released the pellets from the multiparticulate tablet. Multiparticulate sustained release tablets were evaluated for hardness, friability, drug content, disintegration test and dissolution test.

\section{Scanning electron microscopy}

The morphology of the surfaces and cross sections of the coated pellets were examined before and after compression by scanning electron microscopy (SEM) (Tunon A., 2003). The dried samples were coated by platinum coating using an auto fine coater (JEOL-JFC 1600, Japan) and then observed under different magnifications with an analytical scanning electron microscope (JEOL-JSM 6360A, Japan).

\section{Stability testing protocol}

Coated pellets were packaged and sealed in $20 \mathrm{~g}$ quantities in high density amber colored bottles. These bottles were then placed inside stability testing instruments (Scientific equipment Pvt. Ltd., Mumbai) previously equilibrated to $25^{\circ} \mathrm{C} / 60 \%$ relative humidity $(\mathrm{RH})$. At predetermined time intervals, bottles were pulled out from stations and tested for dissolution (Shao, 2002).

\section{RESULT AND DISCUSSION}

\section{Physical characteristics of pellets}

Non pareil seeds and sustained release pellets having Carr's index value in the range $14-16 \%$ and angle of repose of $22-24^{0}$ showed good flow property (Aulton, 2002).

\section{Drug Content}

Amount of drug in pellets was found to be $11 \%$ estimated spectrophotometrically.

\section{In vitro dissolution data analysis}

In $3^{2}$ full factorial design, various factors were studied using all the possible combinations, as it was considered to be most efficient for estimating the influence of individual variables (main effects) and their interactions, using minimum experimentation (Figure 1).

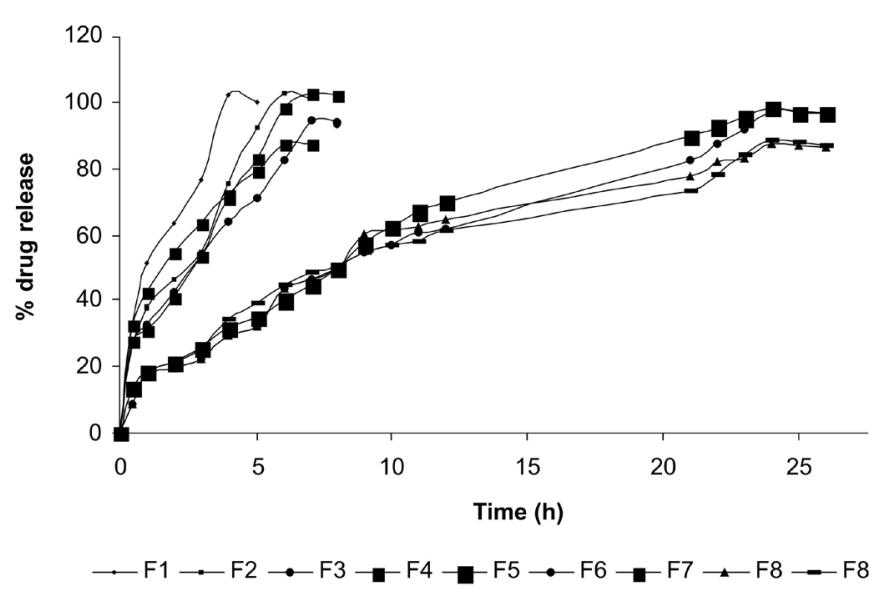

FIGURE 1 - Dissolution profile of sustained release formulations of metoprolol succinate pellets $\{$ Mean $(\mathrm{N}=3)\}$.

From the dissolution profile, it was concluded that batches F1-F3 of the ratio 70:30 released drug from $97.21 \pm 1.91 \%$ to $103.26 \pm 1.13 \%$ for up to $6-7 \mathrm{~h}$, respectively. Batches F4-F6 of the ratio 80:20 released drug from $98.57 \pm 0.49 \%$ to $104.9 \pm 2.25 \%$ up to $20-24 \mathrm{~h}$, respectively, and F7-F9 of the ratio 90:10 released drug from $88.08 \pm 2.14 \%$ to $95.68 \pm 0.6 \%$ up to $20-24 \mathrm{~h}$, respectively (Table V). 
TABLE V - Percent cumulative release of $\mathrm{t}_{50 \%}$ and $\mathrm{t}_{80 \%}$ of metoprolol succinate pellets

\begin{tabular}{lcccccc}
\hline Sr.No. & Formulations & Polymer ratio & Coating load & $\begin{array}{c}\text { \% Cumulative } \\
\text { release (S.D.) }\end{array}$ & ${\text { Average } \mathrm{t}_{50 \%}(\mathrm{~h})}$ & ${\text { Average } \mathrm{t}_{80 \%}(\mathrm{~h})}$ \\
\hline 1 & F1 & $70: 30$ & 15 & $102.13 \pm 2.65$ & 1.17 & 1.83 \\
2 & F2 & $70: 30$ & 20 & $103.26 \pm 1.13$ & 2.33 & 4.5 \\
3 & F3 & $70: 30$ & 25 & $97.21 \pm 1.92$ & 4 & 5.5 \\
4 & F4 & $80: 20$ & 15 & $104.9 \pm 2.25$ & 2.83 & 6.83 \\
5 & F5 & $80: 20$ & 20 & $99.17 \pm 0.71$ & 8.17 & 14.17 \\
6 & F6 & $80: 20$ & 25 & $98.57 \pm 0.49$ & 8.42 & 15.83 \\
7 & F7 & $90: 10$ & 15 & $95.68 \pm 0.6$ & 3.17 & 5.25 \\
8 & F8 & $90: 10$ & 20 & $94.17 \pm 1.69$ & 7.08 & 15.5 \\
9 & F9 & $90: 10$ & 25 & $88.08 \pm 2.14$ & 7.17 & 16 \\
\hline
\end{tabular}

The results are the mean and standard deviation (S.D.) of five replicates.

\section{Study of regression coefficient $\left(r^{2}\right)$ of different kinetic models}

Different kinetic models were studied from dissolution profile of the different formulations of metoprolol succinate sustained release pellets as shown in Table VI.

The general polynomial equation for percent release in terms of coded factors using multiple linear regression analysis is -

$\mathrm{Y}=\beta_{0}+\beta_{1} \mathrm{X}_{1}+\beta_{2} \mathrm{X}_{2}+\beta_{3} \mathrm{X}_{1} \mathrm{X}_{2}+\beta_{4} \mathrm{X}_{1}^{2}+\beta_{5} \mathrm{X}_{2}^{2}+\beta_{6} \mathrm{X}_{1}$ $\mathrm{X}_{2}{ }^{2}+\beta_{7} \mathrm{X}_{2} \mathrm{X}_{1}{ }^{2}+\beta_{8} \mathrm{X}_{1}^{2} \mathrm{X}_{2}^{2}$

Where $\mathrm{Y}$ represents the measured response and $\mathrm{X}_{1}$ represents the value of the factors. $\beta_{0}, \beta_{1}, \beta_{2} \ldots$ are the constants representing the intercept, coefficients of first-order terms, and coefficients of second-order quadratic terms, respectively. Further data was obtained by putting design experts results into the above polynomial equation.

$\%$ Cumulative Release $=+97.50-4.83 * X_{1}-1.47 * X_{1}^{2}-$ $2.64 * \mathrm{X}_{2}-0.68 * \mathrm{X}_{2}^{2}+0.41 * \mathrm{X}_{1} \mathrm{X}_{2}+0.59 * \mathrm{X}_{1}^{2} \mathrm{X}_{2}-0.14 * \mathrm{X}_{1}$ $\mathrm{X}_{2}^{2}-0.66 * \mathrm{X}_{1}^{2} \mathrm{X}_{2}^{2}$

$\mathrm{t}_{50 \%}=+4.93+1.65 * \mathrm{X}_{1}-0.77 * \mathrm{X}_{2}+2.07 * \mathrm{X}_{1}{ }^{2}-$ $0.47 * \mathrm{X}_{2}^{2}+0.29 * \mathrm{X}_{1} \mathrm{X}_{2}-0.36 * \mathrm{X}_{1}^{2} \mathrm{X}_{2}-0.36 * \mathrm{X}_{1} \mathrm{X}_{2}^{2}+0.19 *$ $\mathrm{X}_{1}^{2} \mathrm{X}_{2}^{2}$

$\mathrm{t}_{80 \%}=+9.49+4.15 * \mathrm{X}_{1}-1.39 * \mathrm{X}_{1}{ }^{2}+3.90 * \mathrm{X}_{1}-0.95 * \mathrm{X}_{2}{ }^{2}$ $+1.77 * \mathrm{X}_{1} \mathrm{X}_{2}-0.30 * \mathrm{X}_{1}{ }^{2} \mathrm{X}_{2}-0.67 * \mathrm{X}_{1} \mathrm{X}_{2}{ }^{2}-003 * \mathrm{X}_{1}{ }^{2} \mathrm{X}_{2}{ }^{2}$

Table VI indicates the best-fit model for each formulation. The model was calculated based on the value of coefficient of regression closest to 0.9999 . Out of a total

TABLE VI - Kinetic models showing drug release pattern of F1-F9 formulations

\begin{tabular}{lccccc}
\hline Formulations & $\begin{array}{c}\text { Zero-order kinetics } \\
\left(\mathrm{r}^{2}\right)\end{array}$ & $\begin{array}{c}\text { First-order } \\
\text { kinetics }\left(\mathrm{r}^{2}\right)\end{array}$ & $\begin{array}{c}\text { Korsemeyer-Peppas } \\
\left(\mathrm{r}^{2}\right)\end{array}$ & Higuchi $\left(\mathrm{r}^{2}\right)$ & Hixen-Crowel $\left(\mathrm{r}^{2}\right)$ \\
\hline F1 & 0.9355 & 0.8397 & 0.9349 & 0.9633 & 0.8762 \\
F2 & 0.9708 & 0.8998 & 0.9719 & 0.97 & 0.9197 \\
F3 & 0.9635 & 0.8848 & 0.9649 & 0.9767 & 0.9084 \\
F4 & 0.9714 & 0.9026 & 0.975 & 0.9767 & 0.9277 \\
F5 & 0.9967 & 0.9488 & 0.9803 & 0.9933 & 0.9402 \\
F6 & 0.9917 & 0.8715 & 0.9611 & 0.99 & 0.9381 \\
F7 & 0.9 & 0.7997 & 0.917 & 0.9567 & 0.849 \\
F8 & 0.9783 & 0.8147 & 0.884 & 0.98 & 0.8585 \\
F9 & 0.9853 & 0.9295 & 0.9792 & 0.99 & 0.9135 \\
\hline
\end{tabular}


TABLE VII - Kinetic models showing drug release pattern of formulated and marketed formulation

\begin{tabular}{llcccc}
\hline Formulations & Best-fit model & $\mathrm{r}^{2}$ & $\begin{array}{c}\% \text { cumulative } \\
\text { release }\end{array}$ & $\begin{array}{c}\mathrm{t} 50 \% \\
(\mathrm{~h})\end{array}$ & $\begin{array}{c}\mathrm{t} 80 \% \\
(\mathrm{~h})\end{array}$ \\
\hline Prepared formulation & Zero-order kinetics & 0.9954 & $93.87 \pm 0.5036$ & $6.5 \pm 0.4$ & $12.75 \pm 0.5$ \\
Marketed formulation & Higuchi & 0.9991 & $94.24 \pm 0.4866$ & $8.0 \pm 0.5$ & $13.5 \pm 0.5$ \\
\hline
\end{tabular}

of nine formulations, F1, F3, F4, F9 followed the Higuchi model. Formulations F2, F5, F6, F7, and F8 followed zero- order kinetics.

\section{Comparative study of dissolution profile of optimized formulation and marketed formulation}

From data obtained by the feasibility search method, the formulation batch of ratio $80: 20$ of coating load $22.5 \%$ was selected for further study. The dissolution profile of the optimized formulation of sustained release pellets was compared with the marketed matrix tablet formulation as shown in Figure 2 whereas kinetics parameters studied are shown in Table VII. Similarity factor $(f 2)$ was calculated using PCP-DISSO software and found to be 79.43.

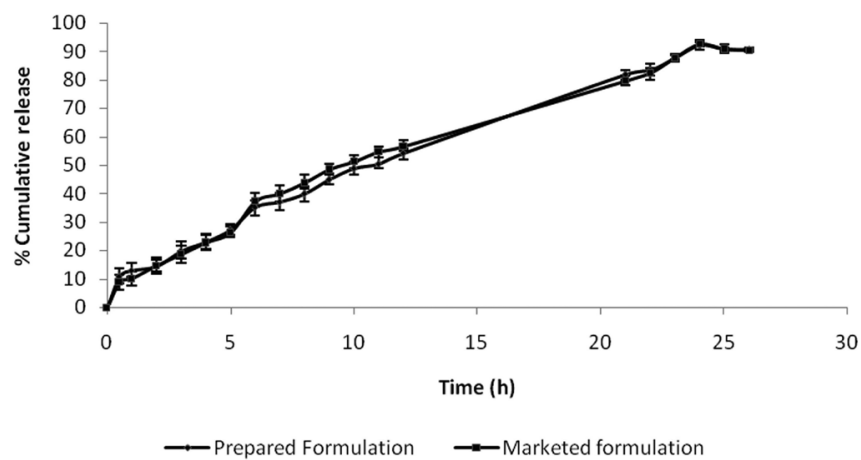

FIGURE 2 - Comparative study of dissolution profile of optimized formulation and marketed Formulation.

\section{Metoprolol succinate sustained release multiparticulate tablet}

\section{Characterization of metoprolol succinate} multiparticulate sustained release tablet

The evaluation parameters of multiparticulate tablet of tablet size, tablet thickness, weight variation, hardness, friability, drug content and uniformity of content were as depicted in Table VIII.

\section{Dissolution profile}

The dissolution profile of multiparticulate sustained release tablet was compared with sustained release marke-

TABLE VIII - Evaluation parameters of multiparticulate tablet

Tablet size

Tablet thickness

Weight variation

Hardness

Friability

Drug content

Uniformity of content

ted matrix tablet. The similarity $(f 2)$ factor was calculated using PCP-DISSO software and found to be 76.46.

From the value of regression coefficient $\left(\mathrm{r}^{2}\right)$, the best fit model was found to follow zero order kinetics with $\mathrm{r}^{2}$ as 0.9939 . The $t_{50 \%}$ and $t_{80 \%}$ of multiparticulate tablet was found to be $7.2 \pm 0.4 \mathrm{~h}$ and $13.5 \pm 0.5 \mathrm{~h}$, respectively (Figure 3).

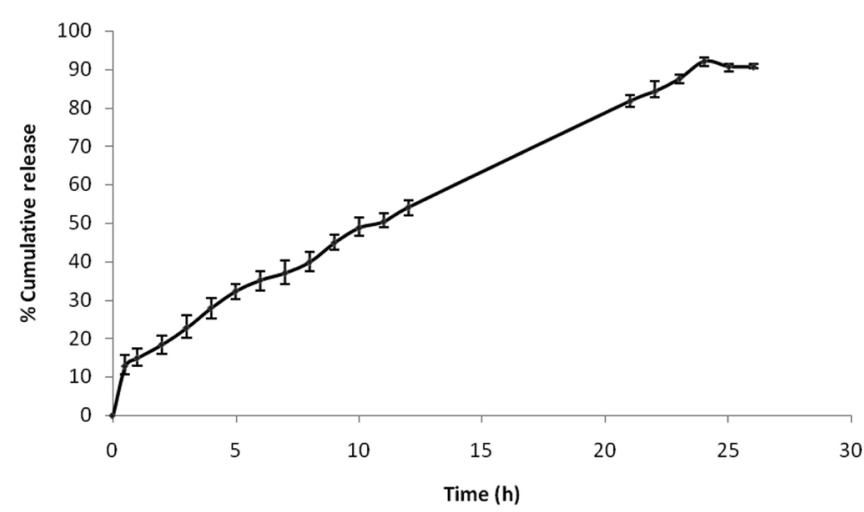

FIGURE 3 - Dissolution profile of sustained release multiparticulate tablet formulation.

Scanning electron microscopy of non pareil seeds, coated pellets and compressed sustained release pellets

The coatings of non pareil seeds, coated pellets and sustained release pellets after compression were studied by scanning electron microscopy at both low and high magnifications. The coated pellets at low magnification appeared as spherical discrete units (Figure 4, Figure 6 and Figure 9) 
and the surface morphology at high magnification was not homogenous or smooth, acting as entrance or exit points for the dissolution medium to dissolve the drug (Figure 5, Figure 7, Figure 8 and Figure 10).

\section{Stability data}

Stability data revealed that pellets were stable at $25^{\circ} \mathrm{C} / 60 \%$ relative humidity (RH) for short term stability of three months. The amount of drug in the pellets was found to be the same after three months (Figure11).

The present study investigated the coating effect of a combination of Surelease ${ }^{\circledR}$ and HPMC E15 on drug release of highly water soluble metoprolol succinate in a coating pan. Coated pellets showed good flow properties

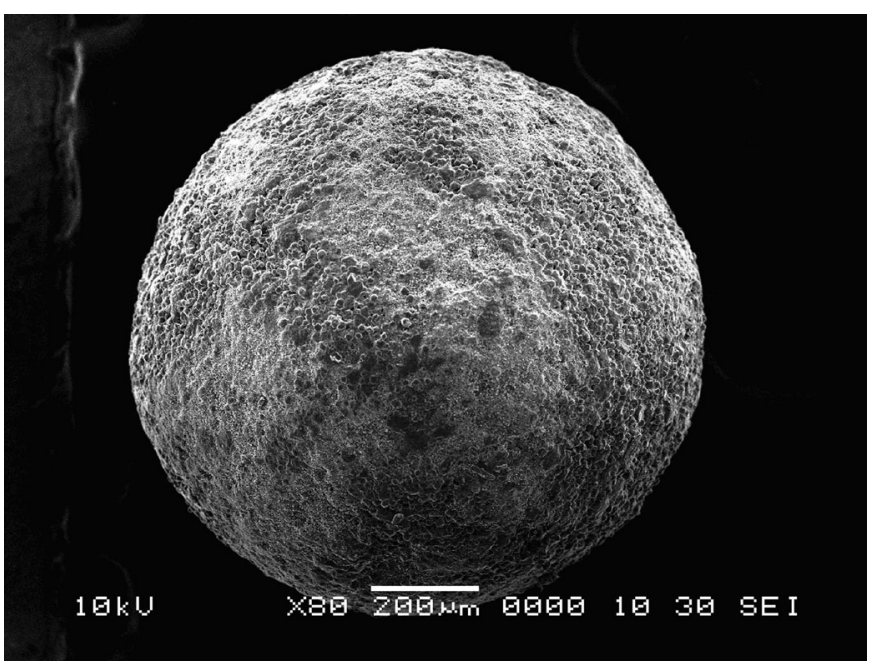

FIGURE 4 - Scanning electron microscopy of non pareil seeds (X80).

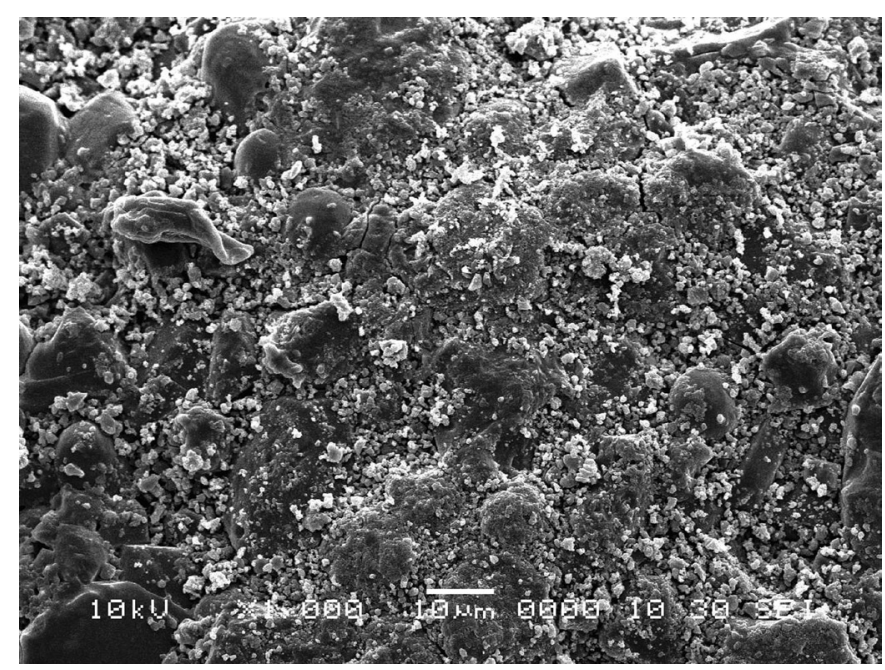

FIGURE 5 - Scanning electron microscopy of non pareil seeds (X1000). for the development of a tablet as a multiparticulate drug delivery system. This film, formed by the combination of these polymers, strongly retarded the permeation of metoprolol, a highly soluble drug, for extended release. The optimization results revealed that metoprolol succinate sustained release pellet of Surelease ${ }^{\circledR}$ and HPMC E15 of $80: 20$ at a $22.5 \%$ coating load showed comparatively better drug release of zero order kinetics than the 90:10 blend. Scanning electron microscopy revealed uniform coating. The surface was uneven at low coating level, but was uniform in an optimized batch of $25 \%$ coating load.

Dissolution data from stability testing revealed that metoprolol succinate was stable with surelease ${ }^{\circledR}$ and hydroxypropyl methylcellulose.

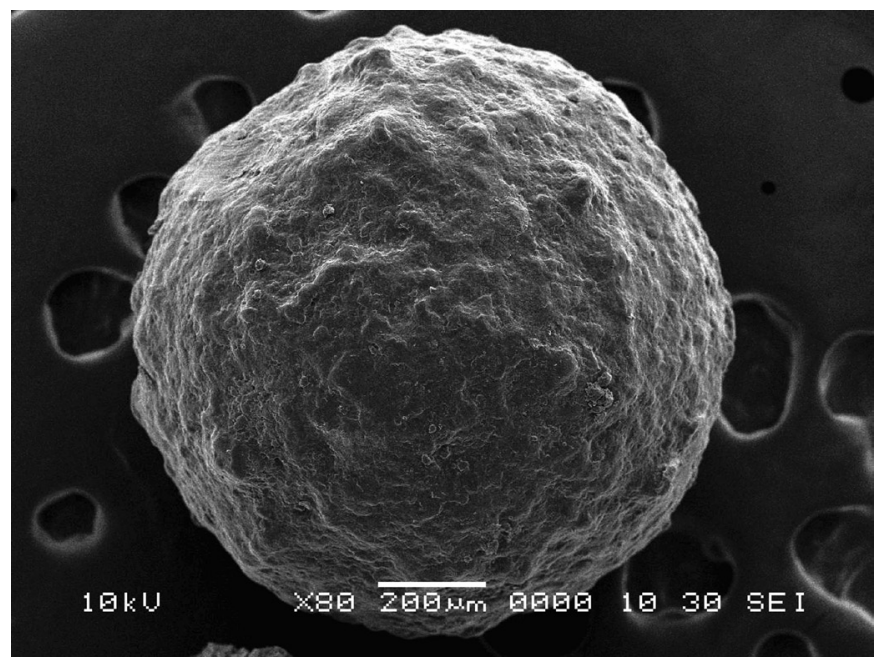

FIGURE 6 - Scanning electron microscopy of polymer coated pellets of an optimized batch F6 (X80).

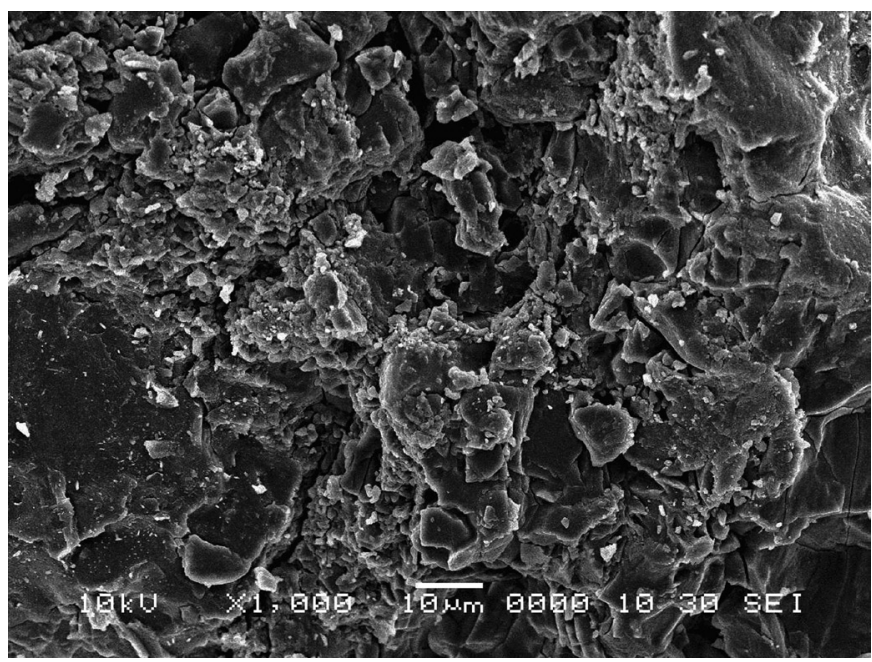

FIGURE 7 - Scanning electron microscopy of polymer coated pellets of an optimized batch F6 (X1000). 


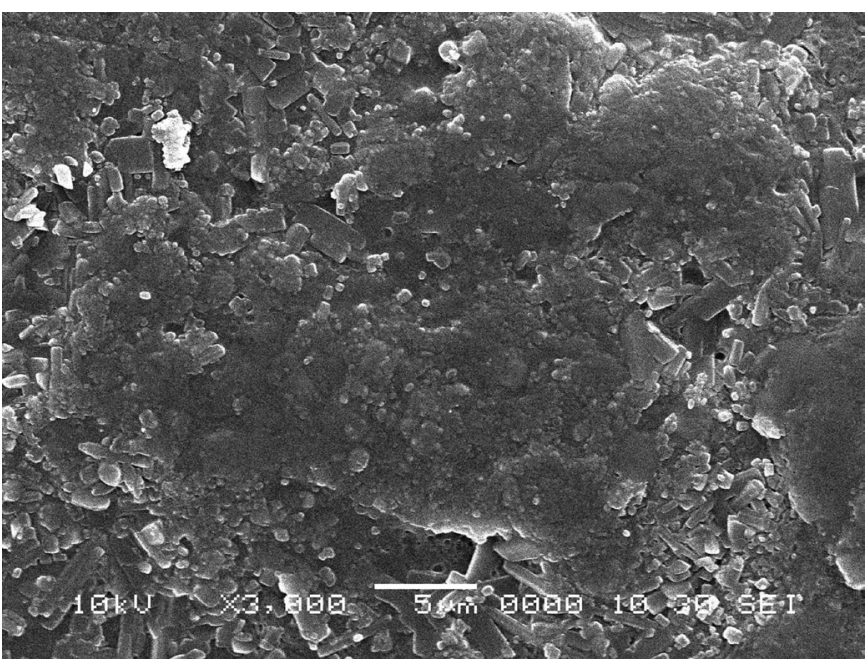

FIGURE 8 - Scanning electron microscopy of polymer coated pellets of an optimized batch F6 (X3000).

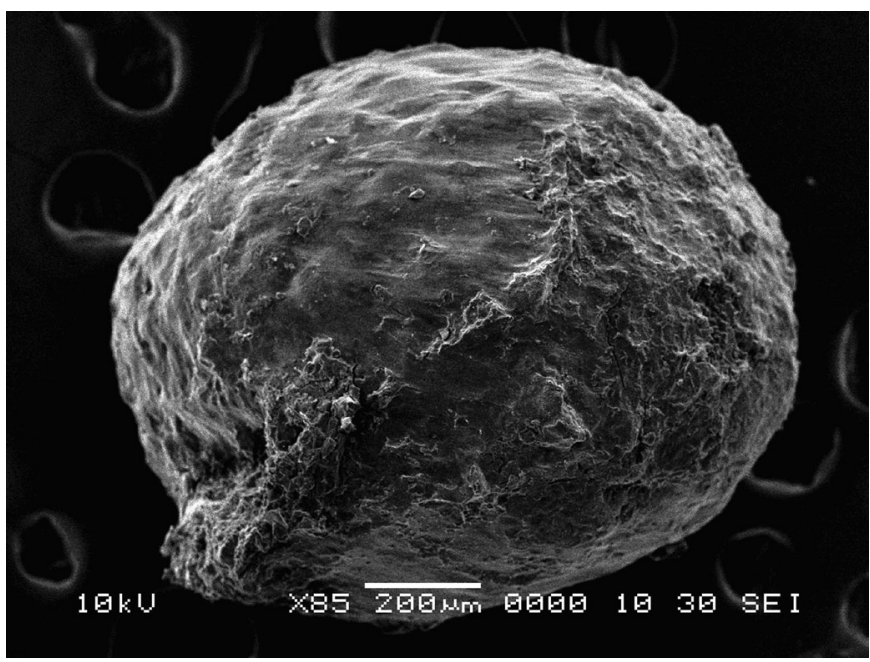

FIGURE 9 - Scanning electron microscopy of sustained release pellets after compression (X85).

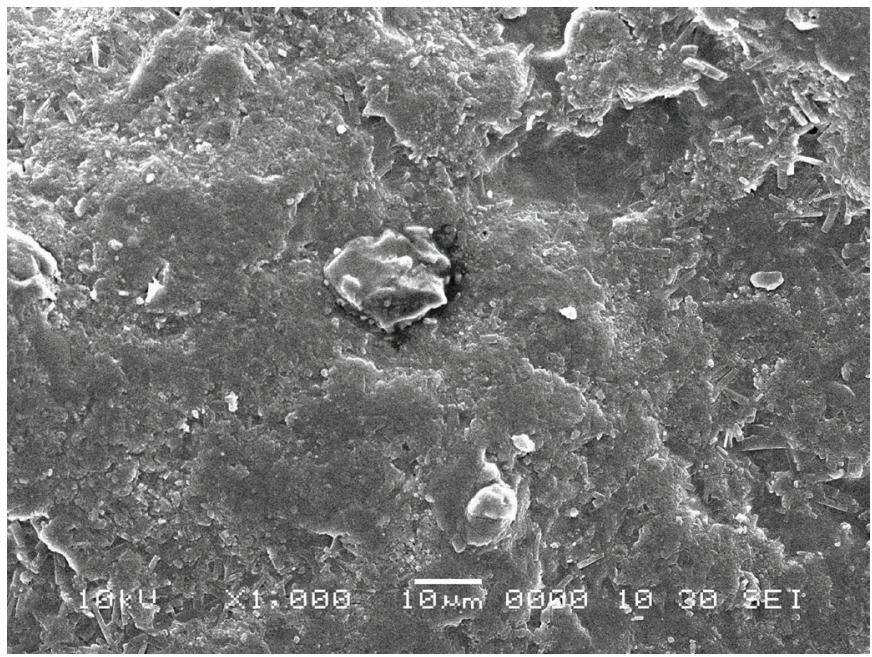

FIGURE 10 - Scanning electron microscopy of sustained release pellets after compression X1000).

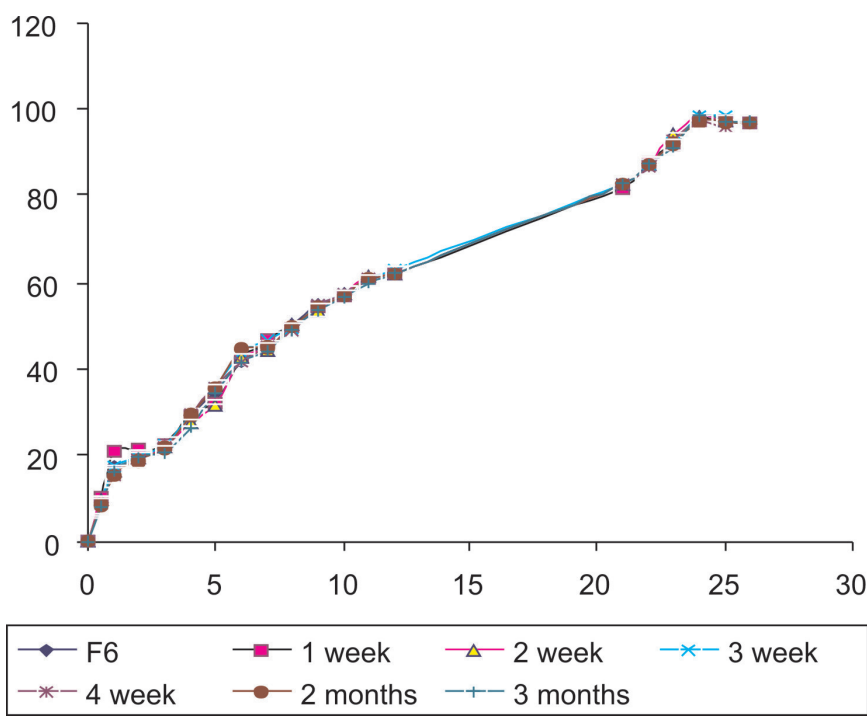

FIGURE 11 - In vitro dissolution profile of indicating stability data of optimized batch F6 after 1 week, 2 weeks, 3 weeks, 1 month, 2 months and 3 months. Mean $(n=3)$.

\section{CONCLUSION}

In this study, we have shown the effect of varying ratios of polymers of Surelease ${ }^{\circledR}$ and HPMC E15 to attain the sustained release property of the pellets formulated in the multiparticulate tablet using an economical pan coating process. In conclusion, the blends of polymer represent the potential formulation factor for the sustained release rate of highly water soluble drugs avoiding the risk of dose dumping.

\section{ACKNOWLEDGEMENTS}

The authors would like to thank Colorcon Pvt. Ltd., Goa for providing a gift sample of Surelease ${ }^{\circledR}$, Salus Pharmaceuticals, Ahmedabad for providing a gift sample of non-pareil seeds, and Ideal cures Pvt. Ltd., Mumbai for providing guidance on coating.

\section{REFERENCES}

AKHGARI, A.F.; SADEGHI, H.; AFRASIABI, G. Combination of time-dependent and $\mathrm{pH}$-dependent polymethacrylates as a single coating formulation for colonic delivery of indomethacin pellets. Int. J. Pharm., v.320, p.137-142, 2006.

AULTON, M.E.; BDUL-RAZZAK, M.H.; HOGAN, J.E. The mechanical properties of hydroxypropylmethylcellulose film derived from aqueous systems. Part 1: the influence of plasticizers. Drug Dev. Ind. Pharm., v.7, p.649-668, 1981. 
EVDOKIA, D. Optimization of the pelletization process in a fluid bed rotor granulator using experimental design. AAPS Pharm Sci. Tech., v.35, p.1-4, 2000.

FRENNING, G.; TUNO'N, A.; ALDERBORN, G. Modeling of drug release from coated granular pellets. J. Control. Rel., v.92, p.113-123, 2003.

GIBALDI, M.; PERRIER, D. Pharmacokinetics. New York: Marcel Dekker, 1982. p.24.

JOHAN, H.; THOMAS, H. Swelling of pellets coated with a composite film containing ethyl cellulose and hydroxypropyl methylcellulose. Int. J. Pharm., v.161, p.23-28, 1998.

LECOMTE, F.; SIEPMANN, J.; WALTHER, M.; MACRAE, R.J.; BODMEIER, R. Polymer blends used for the aqueous coating of solid dosage forms: importance of the type of plasticizer. J. Control. Rel., v. 99, p. 1-13, 2004.

LIAN-DONG, H.; YANG, L.; XING, T.; QIAN, Z. Preparation and in vitro/in vivo evaluation of sustained-release metformin hydrochloride pellets. Eur. J. Pharm. Biopharm., v.64, p.185-192, 2006.

McGINITY, J.W. Aqueous polymeric coatings for pharmaceutical dosage forms. New York: Marcel Dekker, 1997. p.132.

RAHMAN, N., YUEN, K. H., KHAN, N. A., WONG J. W. Drug polymer mixed coating: a new approach for controlling drug release rates in pellets. Pharm. Dev. Technol., v.11, p.71-77, 2006.

REKHI, G.S.; JAMBHEKAR, S.S. Ethylcellulose: a polymer review. Drug Dev. Ind. Pharm., v.21, p.61-77, 1995.
SHAO, R. Drug release from kollicoat SR 30D-coated nonpareil beads: Evaluation of coating level, plasticizer type and curing condition. AAPS Pharm SciTech., v.3, p.2-15, 2002.

SIEPMANN, F.; SIEPMANN, J.; WALTHER, M.; MACRAE, R.J.; BODMEIER, R. Blends of aqueous polymer dispersions used for pellet coating: Importance of the particle size. J. Control. Rel., v.105, p.226-239, 2005.

SOUSA, J.J.; SOUSA, A.; MOURA, M.J.; NEWTON, J.M. The influence of core materials and film coating on the drug release from coated pellets. Int. J. Pharm., v.233, p.111-122, 2002.

TUNON, A. Preparation of tablets from reservoir pellets with an emphasis on the compression behavior and drug release. Uppsala, 2003. p.29-35. [Dissertation for the degree of doctor of philosophy. Faculty of Pharmacy. Uppsala University].

UNITED STATE PHARMACOPOEIA. Rockville: USP Convention, Inc., 2005. p.626, 1279-1281.

VAITHIYALINGAM, S.; KHAN, M.A., Optimization and characterization of controlled release multi particulate beads formulated with a customized cellulose acetate butyrate dispersion. Int. J. Pharm., v.234, p.179-193, 2002.

YE, Z.W.; ROMBOUT, P.; REMON, J.P.; VERVAET, C.; MOOTER, G.V. Correlation between the permeability of metoprolol tartrate through plasticized isolated ethylcellulose/hydroxypropyl methylcellulose films and drug release from reservoir pellets. Eur. J. Pharm. Biopharm., v. 67, p.485-490, 2007

Received for publication on $10^{\text {th }}$ January 2009 Accepted for publication on $05^{\text {th }}$ March 2010 